\title{
RELATIONSHIP BETWEEN REPRODUCTIVE HEALTH KNOWLEDGE AND PERSONAL HYGIENE DURING THE MENSTRUAL PERIOD
}

\author{
Gina Fitriyah, Sriyatin \\ Dosen jurusan keperawatan Poltekkes Kemenkes Tasikmalaya \\ Correspondence: mianstwin@yahoo.com
}

\begin{abstract}
Reproductive health issues are threatening adolescents,including when they having menstrual period. It may because of the usage of pads in a long time, or inappropriate of underwear. WHO (2006) argued that the problems of reproductive health among women remained high $(33 \%)$. This study aimed to analyze the relationship of Reproductive Health Knowledge with Personal Hygiene behavior in the menstrual period.This study was a descriptive correlation with the approach of cross-sectional. The sampling technique was the proportionate stratified random sampling. The samples were 64 respondents. The data were analysed using univariate and bivariate analysis. The result of the study found that the understanding of reproductive health was low category $(46,9 \%)$, moderate $(34,4 \%)$, and high $(18,8 \%)$, meanwhile the personal hygiene when having menstruation in a negative category $(53,1 \%)$ and positive $(46,9 \%)$. There were a significant relationship between reproductive health knowledge and personal hygiene during the menstural period ( $\mathrm{P}$ value 0,82 ). The researcher expected that the respondents should find more information about reproductive health with the problems and do the personal hygiene appropriately in the menstrual period.
\end{abstract}

Keywords: Knowledge, personal hygiene, Menstruation reproductive health

\section{INTRODUCTION}

Adolescents' growth and development are very rapid, both physically and psychologically. One of the physical changes that occur in adolescents, especially women, is menstruation. The average of women's menstruation age is 10.5-15 years (Wong, et al., 2008). Women are threatened by many reproductive health problems including during menstrual period. One of the problems found when women used pads for a long time in the menstrual period, and the type of underwear. Inappropriate pads or underwear would be affected women's health issues including irritation or allergy (Sidohutomo, 2011).

According to WHO (2006) female reproduction health problems were quite large, about $33 \%$ of the total women's diseases worldwide. Demographic data showed that one-fifth of the world's population were adolescents aged 10-19 years. A study conducted in South Asia especially South Bengal about the cleanliness of reproductive organs during menstruation found that the majority of participants had poor cleanliness of reproductive $67.5 \%$ of 160 girls was $32.5 \%$ good and was in moderate level (Tartylah, 2011)

A study conducted by Anggraeni and Mawarni (2008) at RSU Tanggerang found that adolescents' personal hygiene during the menstrual period was poor $(77.5 \%)$ 
(http://www.scribd.com/doc/54113455/jurnal-fkm-unmul downloaded on January 2, 2015). Dai'yahs (2004) study of 58 female students at Medan Public High School 2 found that external reproductive organs care had a good category of 15 (25.86\%), moderate 39 (67.24\%) and poor categories 4 (6, 8\%). In addition, a study conducted by Handayani (2003) in East Jakarta Junior High School found that student received limited knowledge of genital organ hygiene was 93.4\% (http://www.jurnal-perawatan-organ-reproduction-part-out was downloaded on the 20th January 2015).

Maria's (2013) research about the relationship between reproductive health knowledge and the incidence of vaginal irritation during menstruation in adolescents in Manado Public Middle School. Her study found that $40.1 \%$ of respondents had less knowledge of the incidence of vaginal irritation (http://www.academia.edu/7034521/3264 downloaded on January 21, 2015). In West Java Province $11,358,704$ people or $26.60 \%$ of the total population in West Java are adolescents aged 10-24 years. Based on data from PKBI 2010, there was a research on teens. The study involved 2,479 students of junior and senior high school students involving year 11-17 years, the study found that $52.67 \%$ of respondents had inadequate reproductive health knowledge, and their source of knowledge were their friends.

A study conducted at Jatiwangi Islamic High School with the interview technique found that the school provided information about reproductive health education.

The results of the preliminary study on February 26, 2015, found that the total number of students of SMAN 1 Kasokandel in Majalengaka Regency was 176 female students. The Interviews with 10 students found they did not know about reproductive health especially knowledge of personal hygiene during the menstrual period. This study aimed to analyze the relationship of Reproductive Health Knowledge with Personal Hygiene behavior in the menstrual period.

\section{METHODS}

The research was a descriptive correlational study with a cross sectional approach. The population in this study were all students of SMAN 1 Kasokandel total 176 students. The sampling technique in this study uses proportionate stratified random sampling, which is a proportional retrieval technique to obtain a representative sample.

\section{RESULTS}

Level of Reproductive Health Knowledge 
Table 5.1 Levels of Knowledge (n=64)

\begin{tabular}{ccc}
\hline Levels of Knowledge & Frequency (n) & Persentase (\%) \\
\hline High & 12 & 18,8 \\
Moderate & 22 & 34,3 \\
Low & 30 & 46,9 \\
\hline Total & 64 & 100,0 \\
\hline
\end{tabular}

Table 5.1 shows that the majority of respondents had low knowledge of reproductive health $(46.9 \%)$

The media of information

There were four media sources of information in this study: printed media, electronic media, social media, and direct media.

Tabel 5.2 The media of information

\begin{tabular}{ccc}
\hline Media of Information & Frequency (n) & Persentase (\%) \\
\hline Printed Media & 11 & 17,2 \\
Electronic Media & 7 & 10,9 \\
Social Media & 13 & 20,3 \\
Direct Media & 33 & 51,6 \\
\hline Total & 64 & 100,0
\end{tabular}

Table 5.2 shows the results of the frequency distribution of information media dominated by direct media (51.6\%).

Personal Hygiene during the Menstrual period

In this study personal hygiene during menstruation divided into two categories: positive and negative. 
Tabel 5.3 Personal Hygiene

\begin{tabular}{ccc}
\hline Personal Hygiene & Frekuensi (n) & Persentase (\%) \\
& & \\
\hline Positif & 30 & 46,9 \\
Negatif & 34 & 53,1 \\
\hline Total & 64 & 100,0
\end{tabular}

Table 5.3 reveals that the majority of respondents had a negative score of hygiene during menstruation were negative personal hygiene during menstruation $(53.1 \%)$ which are genital care when menstruation was not good.

Level of Knowledge Based on the Information sources

Tabel 5.4 Reproductive Health Knowledge Levels based on the information sources

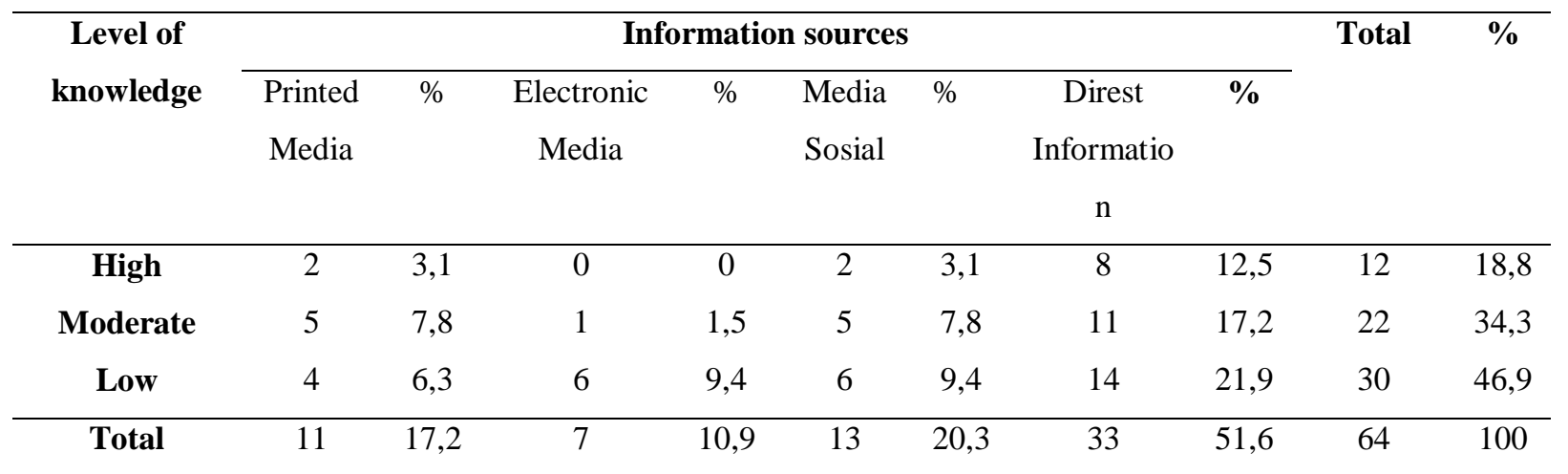

Table 5.4 presents that the most popular media for reproductive health information was direct information $(51.6 \%)$

The Relationship of Reproductive Health Knowledge and Personal Hygiene During Menstruation 
Tabel 5.5 The Relationship of Reproductive Health Knowledge and Personal Hygiene During Menstruation

\begin{tabular}{cccccccc}
\hline Levels of & \multicolumn{3}{c}{ Personal Hygiene } & & total & $\%$ & P Value \\
\cline { 2 - 5 } knowledge & Positif & $\%$ & Negatif & $\%$ & & & \\
\hline High & 12 & 18,8 & 0 & 0 & 12 & 18,8 & 0,821 \\
Moderate & 18 & 28,1 & 4 & 6,3 & 22 & 34,3 & \\
Low & 0 & 0 & 30 & 46,8 & 30 & 46,9 & \\
\hline Total & 30 & 46,9 & 34 & 53,1 & 64 & 100 & \\
\hline
\end{tabular}

Table 5 presents that there was a significant relationship between reproductive health knowledge and personal hygiene during menstruation $\mathrm{P}$ value 0.821

\section{Discussion}

The level of knowledge about reproductive health at students of SMAN 1 Kasokandel, Majalengka was low (46.9\%). The results of the study were the same as the results of a preliminary study of 10 female students at SMAN 1 Kasokandel which stated that the level of female students' knowledge about reproductive health was still lacking. This inline with PKBI's (2001) research data that adolescent respondents $(n=2,479)$, especially high school students, had a low level of reproductive health knowledge. According to Notoatmodjo (2010), knowledge is the result of people's knowing and sense of a particular object. Respondent's knowledge in the level of knowing and understanding because the research questionnaire measured those indicators. Knowing is defined as remembering a material that has been learned before, among others, can mention, describe, identify and state. Understanding is the ability to correctly explain an object that is known and can interpret the material correctly.

Knowledge can be obtained by a person study process either directly or indirectly. Knowledge would also be obtained from various media such as direct media, printed media, electronic media and social media. In this era of globalization, people search for information from social media because internet access is easy.

The positive changes in knowledge are through the educational process. Respondents who were grade $\mathrm{X}$ have learned the problem of human reproductive systems in Biology 
lessons since they were in the junior high school level, so they have got a basic concept of sex education. The results showed that most respondents had a lack of knowledge, but there were still respondents who had good knowledge but only $18.8 \%$ of the 64 respondents. Therefore, it is necessary to increase respondents' knowledge about reproductive health through Adolescent Reproductive Health Counseling.

Based on the results of the study, the majority of respondents obtained information about Reproductive Health through direct media (51.6\%) for example through parents, teachers, relatives, and friends. The majority of lack of knowledge received by respondents through direct media is a number of 14 respondents (21.9\%). The majority of good knowledge was also received by respondents through direct media totaling 8 respondents $(12.5 \%)$. The above results are in accordance with the statement of class X students that they know about reproductive health originating from parents. Even though it was originally from their parent, another source was a friend. Less knowledge received by respondents through direct media, such as parents. This can be caused by different levels of education among parents. The level of education of parents varied from elementary level to tertiary education. This is something that is interrelated because each parent had different ways of providing information about reproductive health to their children. Previous research conducted by Yuliawati (2009) on Muhamadiyah Metro High School students $(n=80)$ found that reproductive health information was mostly obtained from parents and friends $(91.25$

The information received by students from parents was also influenced by the students itself. Students who receive a lot of information would have a different level of knowledge with a student who obtained limited information from their student. This illustrated that the level of parents' education would influence students' knowledge status. The Indonesian culture may also influence students' behavior in searching for information, students were more comfortable to talk about personal matters to their closest people such as parents. According to Notoatmodjo (2007), health problems are influenced by several factors including predisposing factors, others persons, and knowledge. This knowledge itself is influenced by intrinsic and extrinsic factors, including media. Students' knowledge about reproductive health is influenced by media both directly and through other media. The information was both from formal and non-formal education had effected to the knowledge improvement. The environment and information media also influence teenage knowledge, especially about reproductive health (Notoatmodjo, 2007). 
This study found that the majority of grade $\mathrm{X}$ had negative $(53.1 \%)$ personal hygiene during menstruation. There were many respondents who perform genital care inappropiately. This is due to a lack of knowledge of students. This in line with Aisyah Mardani's research in 2010 showed that 36 young women did not have a good personal hygiene behavior, it means $100 \%$ of them did not perform genital care during menstruation properly. According to Azwar (2009) one of the factors that form a positive attitude was a person who considered as an important person, it was parents. The role of parents was very important in forming positive changes to respondents.

In the teenage, this positive aspect of life development is beginning to be formed. Sometimes a teenager showed a positive aspect of a thing, but sometimes they also showed a negative aspect from a behavior. The negative behavior or perspectives were influenced by the lack of knowledge, and be responsible for personal hygiene during the menstrual period. For this reason, it is necessary to pay attention to adolescents in the formation of their development in order to form a positive personality.

The Relationship between Reproductive Health Knowledge and Personal Hygiene During Menstruation At SMAN 1 Kasokandel Students, Majalengka was significant with a $95 \%$ confidence degree and $\alpha=0.05$, the $\mathrm{P}$ value was 0.821 . This study in agreement with Aisyah Mardani's research in 2010 which showed 36 young women or $100 \%$ had less knowledge and none had good personal hygiene behavior. Esther Maria's research in 2013 showed the correlation coefficient of $p$ value 0.499 is a relationship level which is thus $\mathrm{H} 1$ is accepted, there was a relationship between knowledge of reproductive health and the incidence of vaginal irritation during menstruation in adolescents in Manado Public Middle School.

A lack of reproductive health knowledge would be affected by the positive aspects of a person's life. The good knowledge would be affected by the personal hygiene behavior. This is because based on a theoretical study that one of the efforts to reduce problems in the menstrual period was a positive personal hygiene behaviou. According to Budiman and Riyanto (2013), a person's knowledge of an object contains two aspects, positive and negative aspects. Those two aspects would ultimately determine a person's change in a particular object. The more knowledge gained about reproductive health, the more positive behavior of the personal hygiene during the menstrual period. 


\section{CONCLUSION}

Based on the results of the study and discussion, there was a significant relationship between reproductive health knowledge and personal hygiene during the menstrual period. The level of students' knowledge of reproductive health was low. Most of the students in grade X of SMAN 1 Kasokandel obtained information about reproductive health through direct information which is parents. The personal hygiene practice during the menstrual period for grade X students of SMAN 1 Kasocandel is mostly in the negative category of $53.1 \%$.

\section{REFERENCES}

Arikunto, Suharsimi. (2006). Prosedur Penelitian Suatu Pendekatan Praktik Edisi Revisi VI. Jakarta: Rineka Cipta.

Azwar. (2009). Sikap Manusia, Teori dan Pengukurannnya. Jakarta : Pustaka Pelajar

BKKBN. (2012). Kesehatan Reproduksi Kunci Remaja Meraih Bahagia. http://www.bkkbn.go.id/viewartikel.aspx+artikelID=38. Diakses 2 Januari 2015.

Budiaman \& Riyanto. (2013). Kapita Selekta Kuesioner Pengetahuan dan Sikap dalam Penelitian Kesehatan. Jakarta : Salemba Medika.

Dai'yah. (2004). Gambaran tingakat pengetahuan remaja putri tentang perawatan organ reproduksi bagian luar pada siswi SMU Negeri 2 Medan. Medan : Program Studi diploma Keperawatan.

Ester, Maria. (2013). Hubungan pengetahuan kesehatan reproduksi dengan kejadian iritasi vagina saat menstruasi pada remaja di SMP Negeri Manado. Manado :Program Studi Ilmu Keperawatan Fakultas Kedokteran Universitas Sam Ratulangi Manado.

Handayani. (2011). Hubungan pengetahuan, sikap dan perilaku remaja putri tentang kebersihan organ genitalia eksterna di Madrasah Tsanawiyah Pembangunan. Universitas Islam negeri Syarif Hidayatullah.

Hidayat, A. Aziz Alimul. (2007). Metode Penelitian Keperawatan dan Teknik Analisa Data. Jakarta : Salemba Medika.

Ike Anggraeni \& Hesti Suci Marwani. (2008). Jurnal Personal Hygiene remaja. Di akses pada tanggal 2 Januari 2015, http://www.scribd.com/doc/54113455/jurnal-fkmunmul).

Kozier \& Erb. (2009). Buku Ajar Praktik Keperawatn Klinis. Jakarta : EGC.

Kusmiran, Eny. (2011). Kesehatan Reproduksi Remaja dan Wanita. Jakarta : Salemba Medika. 
Lianawati. (2012). Tingkat pengetahuan remaja putri tentang personal hygiene saat menstruasi pada siswi kelas X SMA ISLAM TERPADU AL-MANSYUR PATI. Surakarta : Stikes Kusuma Husada.

Machfoedz, Ircham. (2008). Teknik Membuat Alat Ukur Penelitian. Yogyakarta : Fitramaya.

Mardani, Aisyah. (2010). Hubungan antara Pengetahuan Kesehatan Reproduksi Remaja Putri dengan Perilaku Personal Hygiene Saat Menstruasi di Desa Kedung Kumpul Kecamatan Sarejo-Lamongan. Diakses pada tanggal 20 Mei 2015: //www .scribd.com /doc/54556/jurnalsuryaVol3,No.vii).

Notoatmodjo, Soekidjo.(2005). Metodologi Penelitian Kesehatan. Jakarta : Rineka Cipta. .(2007).Promosi Kesehatan dan Ilmu Perilaku.Jakarta: Rineke Cipta. .(2010). Metodologi Penelitian Kesehatan. Jakarta: Rineka Cipta.

Nursalam. (2013). Metode Penelitian Ilmu Keperawatan. Jakarta : Salemba Medika.

Potter \& Perry. (2005). Fundamental Keperawatan edisi 4. Jakarta : EGC.

Prawirohardjo, Sarwono. (2007). Masa Remaja. Jakarta: EGC.

Proverawati \& Misaroh. (2009). Kesehatan Reproduksi. Yogyakarta; Nuha Medika.

Riyanto, Agus. (2009). Pengolahan Data dan Analisis Data Kesehatan. Yogyakarta : Nuha Medika.

Sarwono, Sarlito Wirawan. (2010).Psikologi Remaja. Jakarta: Rajawali Pers.

Setiadi.(2007). Konsep \& Penulisan Riset Keperawatan. Yogyakarta: Graha Ilmu

Sidohutomo, A. (2011). Kebersihan organ intim saat menstruasi. Di akses pada tanggal 2 Januari 2015, (http://www.scribd.com/doc/54113455/jurnal-fkm-unmul).

Sugiyono, Prof, Dr. (2013). Statistika untuk Penelitian. Bandung : Alfabeta.

Tartylah. (2011). Kebersihan organ reproduksi pada saat menstruasi di Asia Selatan di daerah Bengal Selatan. Diakses pada tanggal 20 Januari 2015 (http://www.personalhygiene menstruasi.com/903051/324)

Tim Penulis Poltekkes Depkes Jakarta I. (2010). Kesehatan Remaja Problem dan Solusinya. Jakarta : Salemba Medika.

Wartonah.(2010) Personal Hygiene. Jakarta; PT Elex Media.

Wong, et al. (2008). Buku Ajar Keperawatan Pediatrik. Jakarta : EGC.

Wylie, Linda. (2010). Esensial Anatomi \& Fisiologi dalam Asuhan Maternitas. Jakarta : EGC. 
Yuliawati. (2009). Gambaran Tingkat Pengetahuan Kesehatan Reproduksi pada Siswi SMU Muhamadiyah Metro. Diakses pada tanggal 26 Mei 2015 (http://www.pengetahuankespro/45677/32) 